\title{
Industrial Wastes in Soil Improvement
}

\author{
G. V. Rama Subbarao, D. Siddartha, T. Muralikrishna, K. S. Sailaja, and T. Sowmya \\ Department of Civil Engineering, S.R.K. Institute of Technology, Enikepadu, Vijayawada 521108, Andhra Pradesh, India
}

Correspondence should be addressed to G. V. Rama Subbarao, gvrs_svu@in.com

Received 11 June 2011; Accepted 18 July 2011

Academic Editors: M. Maslehuddin and D. Zeng

Copyright ( $) 2011$ G. V. Rama Subbarao et al. This is an open access article distributed under the Creative Commons Attribution License, which permits unrestricted use, distribution, and reproduction in any medium, provided the original work is properly cited.

\begin{abstract}
Soil existing at a particular site may not be appropriate for construction of engineering structures. The present study made an attempt to enhance the geotechnical properties of a soil replaced with industrial wastes having pozzolanic value like rice husk ash (RHA) and fly ash (FA). Soil is replaced with RHA in 2\%, 4\%, and 6\% to dry weight of soil. It is observed that soil replaced with $4 \%$ RHA is the optimum for the soil used in this study from geotechnical point of view. To know the influence of fly ash, soil is further replaced with 4\% FA along with 4\% RHA. It is found that results of soil replacement by both RHA and FA proved to be soil modification and not the improvement. Hence, a cost-effective accelerator like lime is used for further replacing the above soil-4\%, RHA-4\% FA mix. The optimum lime content is found to be $4 \%$.
\end{abstract}

\section{Introduction}

Soil is the basic construction material. It supports the substructure of any structure and it is the subgrade which supports the subbase/base in the pavement. The existing soil at a particular location may not be suitable for the construction due to poor bearing capacity and higher compressibility or even sometimes excessive swelling in case of expansive soils. The improvement of soil at a site is indispensible due to rising cost of the land, and there is huge demand for high rise buildings. There is a need to concentrate on improving properties of soils using costeffective practices like treating with industrial wastes those having cementitious value. In this study, industrial wastes like rice husk ash (RHA), fly ash (FA) are used to improve geotechnical properties of a soil.

Rice is the primary source of food for billions of people around the world. Rice husk is the shell produced during dehusking of paddy. India is the second largest producer of rice, next to China. The amount of annual rice husk produced in India is approximately 12 million tons [1]. RHA is obtained from the burning of rice husk which is the byproduct of rice milling. It was estimated that $1000 \mathrm{~kg}$ of rice grain produced $200 \mathrm{~kg}$ of rice husk and on burning the rice husk about $20 \%$ or $40 \mathrm{~kg}$ would become RHA. RHA has the potential to be used as a substitute for silica fumes or microsilica at a much lower cost. Adding RHA to the concrete mix even in low replacement will dramatically enhance the workability, strength, and impermeability of concrete mixes, while making the concrete durable to chemical attacks, abrasion, and reinforcement corrosion, increasing the compressive strength. Keeping in view of environmental consideration, energy conservation, and economy, reactive ash production can lead to excellent technological benefits useful to the community at large [2]. Well-burnt RHA passed through $425 \mu$ was used in this investigation for convenient mixing with clay and compaction. Several investigators studied the influence of RHA in soil stabilisation [3-5]. Some of researchers studied the effect of RHA-FA on soil properties [6] and also effect of RHA-lime on characteristics of soil [7-11].

FA is the finely divided mineral residue resulting from the combustion of ground or powdered coal in electric generating plant. ASTM C 618 provides the classification requirements for fly ash. There are two types of fly ashes namely Class C and Class F [12]. From pozzolanic point of view the Indian coal ashes fall in the category of class F. In view of their good physical properties, they can be used beneficially in most of the geotechnical applications [13]. In recent years, the engineering community feels that bulk utilization of ash is possible through geotechnical 
TAble 1: Properties of soil.

\begin{tabular}{lc}
\hline Property & Value \\
\hline Specific gravity & 2.69 \\
Gravel & $0 \%$ \\
Sand & $14.17 \%$ \\
Fines & $85.83 \%$ \\
Liquid limit & $76.89 \%$ \\
Plastic limit & $40.43 \%$ \\
Plasticity index & $36.46 \%$ \\
Classification of soil (USCS) & $\mathrm{MH}$ \\
Differential free swell index (DFSI) & $70 \%$ \\
Degree of expansivity & Very High \\
Maximum dry density (MDD) & $1.498 \mathrm{Mg} / \mathrm{m}^{3}$ \\
Optimum moisture content (OMC) & $26.1 \%$ \\
pH value & 8.6 \\
\hline
\end{tabular}

applications [14]. Use of coal ashes for stabilization of soil resolve the clash between development and environment as it involves reuse and safe riddance of hazardous coal ashes. At present, nearly 75 percent of India's electricity generation is met by coal-based thermal power stations.

Utilisation of industrial wastes such as RHA and FA for soil improvement is a sustainable and cost-effective technique. Geotechnical properties studied in this investigation includes Index properties like liquid limit, plastic limit, and differential free swell index, and engineering properties like compaction and strength characteristics of soil with and without replacement of various proportions of RHA. Soil is replaced with RHA in 2\%, 4\%, and 6\% to dry weight of soil. It is observed that soil replaced with $4 \%$ RHA is the optimum RHA (ORHA) for the soil used in this study from view point of plasticity, swelling, and strength. In order to understand the effect of fly ash, soil is replaced with 4\% FA together with $4 \%$ RHA. It is found that geotechnical properties of soil replacement by both RHA and FA proved to be modifying properties of soil not for the enhancement. Hence a low cost accelerator like lime (L) is used for further replacing the above soil-4\%RHA-4\%FA mix. To find OLC, Eades and Grim $\mathrm{pH}$ method [15] is adopted, and OLC is $4 \%$ for the above mix. The OLC is proved to be $4 \%$ from geotechnical properties for soil-4\%RHA-4\% FA mix.

\section{Materials Used}

2.1. Soil. The soil used in this study was obtained from Enikepadu, Vijayawada $\left(16^{\circ} 31^{1}\right.$ North Latitude $80^{\circ} 39^{1}$ East Longitude), Andhra Pradesh, India. It was collected by open excavation, from a depth of $0.5 \mathrm{~m}$ below natural ground level. The properties of the soil are evaluated and presented in Table 1 . The soil chosen in this investigation is silty clay (MI) [16] and having high degree expansivity.

2.2. Rice Husk Ash. Rice husk is an agricultural residue abundantly available in rice producing countries. RHA is obtained from the burning of rice husk which is the byproduct of rice milling. The chemical properties of RHA are mentioned in
TABle 2: Chemical composition of rice husk ash.

\begin{tabular}{lc}
\hline Constituent & Percentage \\
\hline Silica $\left(\mathrm{SiO}_{2}\right)$ & 91.1 \\
Alumina $\left(\mathrm{Al}_{2} \mathrm{O}_{3}\right)$ & 0.4 \\
Calcium oxide $(\mathrm{CaO})$ & 0.4 \\
Ferric oxide $\left(\mathrm{Fe}_{2} \mathrm{O}_{3}\right)$ & 0.4 \\
Sodium $\left(\mathrm{Na}_{2} \mathrm{O}\right)$ & 0.1 \\
Sulphur $\left(\mathrm{Na}_{2} \mathrm{O}\right)$ & 0.1 \\
Magnesium oxide $(\mathrm{MgO})$ & 0.5 \\
Potassium oxide $(\mathrm{KaO})$ & 2.2 \\
Loss on ignition & 4.8 \\
\hline
\end{tabular}

TABLE 3: $\mathrm{pH}$ test results.

\begin{tabular}{lc}
\hline Material/Mix & $\mathrm{pH}$ value \\
\hline Soil-4\%RHA-4\%FA-2\%L & 11.63 \\
Soil-4\%RHA-4\%FA-4\%L & 12.42 \\
Soil-4\%RHA-4\%FA-6\%L & 12.68 \\
Soil-4\%RHA-4\%FA-8\%L & 12.70 \\
\hline
\end{tabular}

Table 2 as per IPSIT [1]. From the Table 2 it is clear that silica is the major constituent of the rice husk ash. The RHA used in this investigation is obtained from nearby industry. The $\mathrm{pH}$ value of the RHA used in this work is 10.96 .

2.3. Fly Ash. Fly ash has been obtained from the electrostatic precipitator hoppers of Vijayawada thermal power station (VTPS), Ibrahim patnam about $18 \mathrm{~km}$ away from the Vijayawada, India. VTPS consumes about 20,000 tonnes of coal per day, out of which 5,500 tonnes of fly ash is produced. Chemical composition of this fly ash consists of $64.08 \%$ silica, $20.21 \%$ of alumina, $4.17 \%$ of ferric oxide, and $6.20 \%$ of calcium oxide. The fly ash used in this investigation comes under category of Class-F [13]. The specific gravity of fly ash is 2.10 , fraction finer than $75 \mu$ is $79.93 \%$ rest being coarser than $75 \mu$ but finer than $425 \mu$, maximum dry unit weight is $13.63 \mathrm{kN} / \mathrm{m}^{3}$, and optimum moisture content is $21.4 \%$. The $\mathrm{pH}$ value of the FA is 9.64 .

2.4. Lime. Lime is a classical soil stabiliser. Use of lime in the construction industry is an ancient practice from Romans and Egyptians. The most common form of lime used in soil stabilization is hydrated lime (or calcium hydroxide or slaked lime). Commercially available hydrated lime is used in this investigation. The $\mathrm{pH}$ value of lime used in this study is 12.80 . Table 3 shows the $\mathrm{pH}$ test results of soil- $4 \% \mathrm{RHA}-$ $4 \%$ FA with $2 \%, 4 \%, 6 \%$, and $8 \%$ lime. The OLC for the soil$4 \%$ RHA- $\%$ FA mix is obtained from Eades and Grim $\mathrm{pH}$ method [15]. At 4\% L, pH value is nearly and above 12.4, therefore $4 \% \mathrm{~L}$ is the OLC for soil-4\%RHA-4\%FA mix.

\section{Effect of RHA, RHA-FA, and RHA-FA-L on Index Properties}

Liquid limit (LL), plastic limit (PL), and differential free swell index (DFSI) tests are conducted on soil with and without 
TABLE 4: Index properties of soil with replacements.

\begin{tabular}{lcccc}
\hline Soil replaced with & LL $(\%)$ & PL (\%) & PI (\%) & DFSI (\%) \\
\hline 2\% RHA & 77.51 & 39.16 & 38.35 & $60 \%$ \\
4\% RHA & 66.8 & 44.36 & 22.44 & $50 \%$ \\
6\% RHA & 79.14 & 45.66 & 33.48 & $55 \%$ \\
8\% RHA & 78.38 & 44.05 & 34.33 & $60 \%$ \\
10\% RHA & 79.14 & 45.66 & 33.48 & $60 \%$ \\
12\% RHA & 79.86 & 47.82 & 32.04 & $65 \%$ \\
4\%RHA+4\%FA & 40.29 & 30.37 & 9.92 & $40 \%$ \\
4\%RHA+4\%FA+2\%L & 63.11 & 39.39 & 23.72 & $40 \%$ \\
4\%RHA+4\%FA+4\%L & 64.75 & 38.02 & 26.73 & $30 \%$ \\
4\%RHA+4\%FA+6\%L & 56.73 & 37.62 & 19.11 & $40 \%$ \\
\hline
\end{tabular}

replacements as per codal provisions [17]. Plasticity index (PI) is calculated from the deduction of PL from LL. Index properties like LL, PL, and DFSI for soil replaced with $2 \%$, $4 \%, 6 \%, 8 \%, 10 \%$, and $12 \%$ RHA to dry weight of soil are presented in Table 4 . The LL decreased from $76.89 \%$ to $66.80 \%$ with increase in RHA content from $0 \%$ to $4 \%$, respectively. This can be considered as a consequence of the substitute of the soil fines by RHA. The later which has less affinity for water caused the drop in LL. As the RHA was further increased from $4 \%$ to $12 \%$, the LL increased from $66.80 \%$ to $79.14 \%$, respectively. At this stage the RHA quantity increased to an extent that more water will be required to turn the soil-RHA mix to fluid.

The variation of PL is similar to that of the LL with increase in \%RHA. The reasons for the variation of LL with RHA content are also similar to that of the variation of PL with RHA content. PI decreased from $36.45 \%$ to $22.43 \%$ with increase in RHA content from $0 \%$ to $4 \%$. This scenario may be attributed to the replacement of the finer soil particles by the RHA with consequent reduction in the clay content and plasticity index. LL, PI, and DFSI are decreased to $40.29 \%, 9.92 \%$, and $40 \%$ for soil replaced with 4\%RHA$4 \%$ FA. Soil has DFSI of $70 \%$, and it is decreased to $50 \%$, $40 \%$ with $4 \%$ RHA, and $4 \%$ RHA- $4 \%$ FA replacement of soil, respectively. The decrease may be due to increase in coarser particles in soil-RHA-FA mix. Lime in proportions of $2 \%$, $4 \%$, and $6 \%$ also replaced the soil-4\%RHA- $4 \%$ FA mix for the purpose of higher cementation and decontamination. DFSI values for various proportions of soil replacements are presented in Table 4. It is observed that 4\%RHA is optimum with respect to DFSI. Finally, 4\%RHA replacement is the ORHA in view of index properties. Soil replaced with $4 \% \mathrm{RHA}+4 \% \mathrm{FA}$ $+4 \% \mathrm{~L}$ has the DFSI of $30 \%$. Hence, $4 \% \mathrm{~L}$ is the OLC for soil- $4 \%$ RHA $+4 \%$ FA mix in view of index properties.

\section{Effect of RHA, RHA-FA, and RHA-FA-L on Compaction Characteristics}

Standard Compaction tests [18] are conducted on soil with and without replacements. Compaction curves are plotted (Figure 1), and compaction characteristics namely maximum dry density (MDD) and optimum moisture content (OMC) are presented in Table 5. MDD is increased

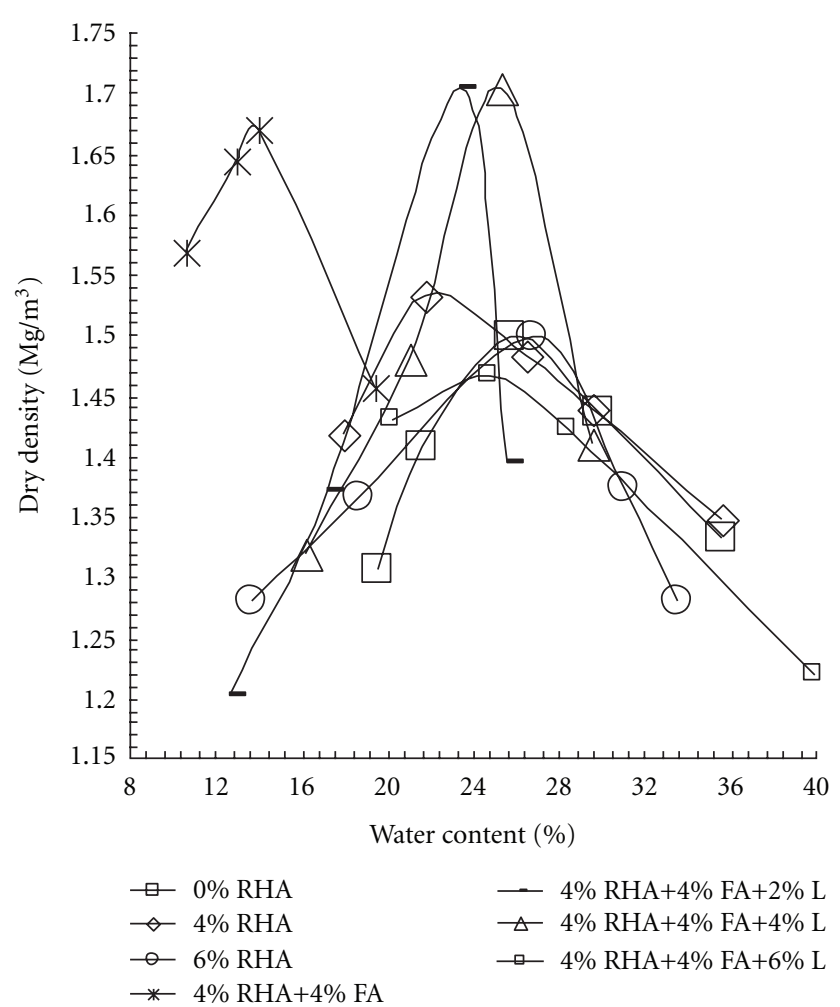

Figure 1: Compaction curves for soil with and without various proportions of replacements.

TABLE 5: Compaction characteristics of soil with replacements.

\begin{tabular}{|c|c|c|}
\hline \multirow{2}{*}{ Soil replaced with } & \multicolumn{2}{|c|}{ Compaction characteristics } \\
\hline & $\begin{array}{c}\text { Maximum dry } \\
\text { density } \\
\left(\text { in } \mathrm{Mg} / \mathrm{m}^{3}\right)\end{array}$ & $\begin{array}{c}\text { Optimum } \\
\text { moisture content } \\
(\%)\end{array}$ \\
\hline 4\% RHA & 1.532 & 22.5 \\
\hline $6 \%$ RHA & 1.499 & 27.0 \\
\hline $4 \% \mathrm{RHA}+4 \% \mathrm{FA}$ & 1.660 & 13.8 \\
\hline $4 \% \mathrm{RHA}+4 \% \mathrm{FA}+2 \% \mathrm{~L}$ & 1.710 & 23.3 \\
\hline $4 \% \mathrm{RHA}+4 \% \mathrm{FA}+4 \% \mathrm{~L}$ & 1.703 & 25.3 \\
\hline $4 \%$ RHA+4\%FA+6\%L & 1.470 & 24.81 \\
\hline
\end{tabular}

up to $4 \%$ RHA and beyond which it decreases while the OMC decreased up to $4 \%$ RHA and beyond which it increases. MDD is increased and OMC decreased with 4\%RHA-4\%FA. MDD and OMC of soil replaced with 4\%RHA-4\%FA-2\%L are $1.710 \mathrm{Mg} / \mathrm{m}^{3}$ and $23.3 \%$. MDD decreases for soil replaced with $4 \%$ RHA-4\%FA-4\%L and 4\%RHA-4\%FA-6\%L. OMC increases for soil replaced with $4 \%$ RHA- $4 \% \mathrm{FA}-4 \% \mathrm{~L}$ and again decreases for soil replaced with $4 \%$ RHA- $4 \% \mathrm{FA}-6 \% \mathrm{~L}$.

\section{Effect of RHA, RHA-FA, and RHA-FA-L on Strength Characteristics}

Unconfined compression tests [19] are conducted on soil specimens with and without replacements for 0- and 7-day curing. The specimens are compacted to their respective 


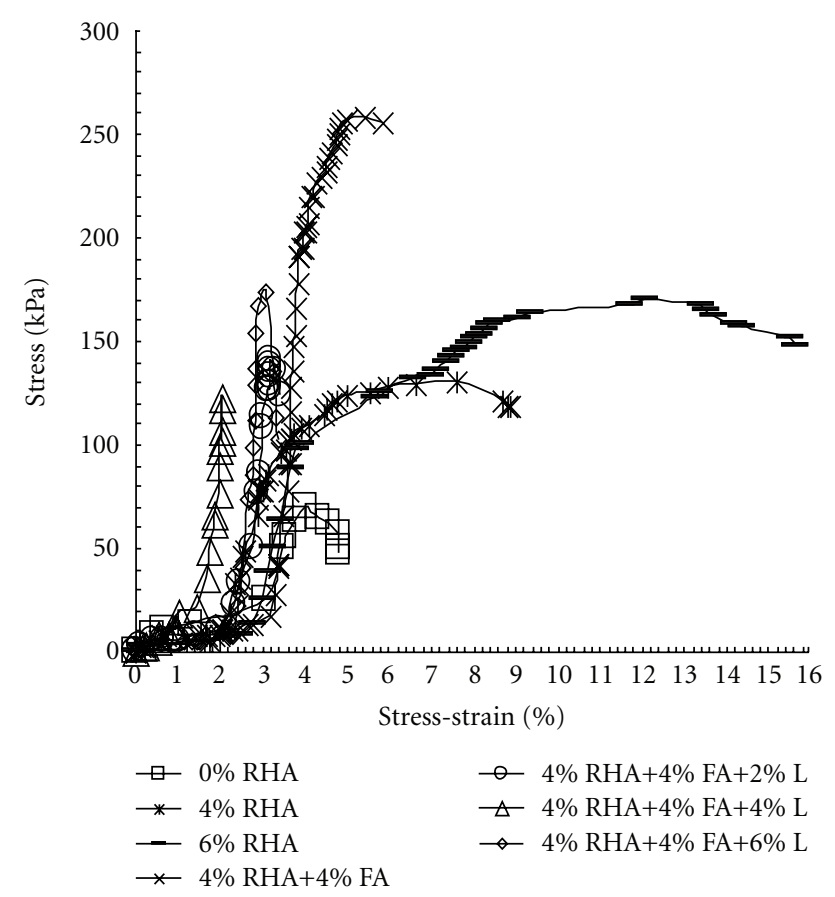

FIGURE 2: Stress-strain plots for uncured specimens.



FIGURE 3: Stress-strain plots for 7-day cured specimens.

MDD's and OMC's of the mixes. Stress-strain plots are shown in Figures 2 and 3 for uncured and cured specimens. Unconfined compressive strength (UCS) and failure strains are summarized in Table 6. There is an increase in UCS value from 70 to $260 \mathrm{kPa}$ for uncured specimens and 70 to $560 \mathrm{kPa}$ for 7 -day cured specimens replaced with $0 \%$ to 6\%RHA. Curing increases the strength due to pozzolanic reaction. Percentage increase in UCS is higher for 4\%RHA. Therefore, 4\%RHA is the ORHA with respect to strength.
TABLE 6: Unconfined compressive strength (ucs) of soil with replacements.

\begin{tabular}{lcccc}
\hline Soil replaced with & \multicolumn{2}{c}{ 0-day curing } & \multicolumn{2}{c}{ 7-day curing } \\
& $\begin{array}{c}\text { UCS } \\
(\mathrm{kPa})\end{array}$ & $\begin{array}{c}\text { Failure } \\
\text { strain } \\
(\%)\end{array}$ & $\begin{array}{c}\text { UCS } \\
(\mathrm{kPa})\end{array}$ & $\begin{array}{c}\text { Failure } \\
\text { strain } \\
(\%)\end{array}$ \\
\hline 0\% RHA & 70.00 & 4.04 & 70 & 4.04 \\
4\% RHA & 129 & 7.60 & 210 & 3.78 \\
6\% RHA & 169 & 12.10 & 240 & 2.68 \\
4\%RHA+4\%FA & 260 & 5.42 & 566 & 3.71 \\
4\%RHA+4\%FA+2\%L & 141 & 3.19 & 484 & 3.5 \\
4\%RHA+4\%FA+4\%L & 122 & 2.08 & 899 & 3.15 \\
4\%RHA+4\%FA+6\%L & 174 & 3.09 & 1204 & 2.81 \\
\hline
\end{tabular}

The decrease in rate of strength increase after 4\% RHA could be attributed to the excess RHA that could not be utilized for the cementation reaction.

UCS for 0-day and 7-day cured soil replaced with $4 \%$ RHA- $4 \% \mathrm{FA}$ increases to $260 \mathrm{kPa}$ and $566 \mathrm{kPa}$, respectively. UCS for 7-day cured soil replaced with 4\%RHA$4 \% \mathrm{FA}-6 \% \mathrm{~L}$ increases to $1204 \mathrm{kPa}$; that is, it is about 1600 times as compared to untreated soil strength. The percentage increase in strength is higher for 7-day cured soil replaced with $4 \%$ RHA- $4 \% \mathrm{FA}-4 \% \mathrm{~L}$ mix. Hence, $4 \% \mathrm{~L}$ is the OLC for soil-4\%RHA- $\%$ FA mix in view of strength. Chemical reactions that occur when soil treated with RHA, FA, and $\mathrm{L}$ includes cation exchange, carbonation, and pozzolanic reactions leading to formation of Calcium-Silicate-Hydrate (C-S-H) gel. This new geometrical can be used as subbase course for pavements [20]. Transport Research Laboratory, UK recommended UCS value of $750-1500 \mathrm{kPa}$ for subbase course of pavements.

\section{Conclusions}

The following conclusions can be drawn from the present investigation.

From view point of Index properties, replacement of soil with $4 \%$ rice husk ash (RHA) is the optimum RHA content. With replacement of $4 \%$ RHA, liquid limit and plasticity Index decrease from $76.8 \%$ to $66.8 \%$ and from $36.45 \%$ to $22.43 \%$, respectively. DFSI is reduced from $70 \%$ to $50 \%$.

Unconfined compressive strength (UCS) is increased with RHA content. The UCS of original soil is $70 \mathrm{kPa}$. For the soil replaced with $4 \%$ RHA and 6\%RHA, the UCS is increased to $88 \%$ and $141 \%$, respectively, as compared to the original soil. The increase in strength is higher when 4\%RHA is replaced as compared to 6\%RHA. Therefore, $4 \%$ RHA is the optimum RHA content.

Curing further improved strength of RHA treated soil. With 7-day curing, UCS of soil replaced with $4 \%$ RHA is increased nearly $60 \%$ as compared to uncured one.

In replacement of soil with $4 \%$ fly ash (FA) together with 4\%RHA, the UCS after 7-day curing is increased to $70 \%$. UCS of 7-day cured soil sample replaced with 4\%RHA$4 \% \mathrm{FA}-6 \% \mathrm{~L}$ mix is increased to $1620 \%$, that is, $1204 \mathrm{kPa}$, 
whereas UCS of 28 -day cured soil-4\%L-12\%RHA mix is $1120 \mathrm{kPa}$ [10]. Hence, fly ash have a significant influence on improvement of strength.

The percentage increase in strength is higher for 7-day cured soil replaced with 4\%RHA-4\%FA-4\%L mix. Hence, $4 \% \mathrm{~L}$ is the optimum lime content for soil-4\%RHA-4\%FA mix in view of strength.

Soil replaced with $4 \%$ RHA- $4 \%$ FA- $4 \%$ L mix improved the properties of soil. This new geomaterial can be used as subbase course for pavements. DFSI for this mix is $30 \%$. Hence, this mix can also used as a cushioning material under the expansive soil bed. Sustainable development can be achieved through making waste materials to wealthy materials.

\section{Acknowledgments}

Authors are thankful to Dr. P. V. Narasaiah, Director of SRK Institute of Technology, Enikepadu, Vijayawada, Andhra Pradesh, India and Dr. K. Mallikarjunarao, Professor in Department of Civil Engineering, Sri Venkateswara University College of Engineering, Tirupati, Andhra Pradesh, India for their constant guidance and support. They are thankful to Mr. Yellamanda Vusa, Assistant Professor in Department of English, SRK Institute of Technology, Enikepadu, Vijayawada, Andhra Pradesh, India for his valuable suggestions in English language used to prepare this paper.

\section{References}

[1] IPSIT, "Precipitated silica from rice husk ash, ," Indian Institute of Science Precipitated Silica Technology, Combustion, Gasification \& Propulsion Laboratory (CGPL), Bangalore, India, http://cgpl.iisc.ernet.in/site/Portals/0/Technologies/PrecipitatedSilica.pdf.

[2] A. Muthadhi, R. Anitha, and S. Kothandaraman, "Rice husk ash- properties and its uses: a review," Journal of the Institution of Engineers, vol. 88, pp. 50-56, 2007.

[3] A. S. Muntohar, "Utilization of uncontrolled burnt RHA in soil improvement," Dimensi Teknik Sipil, vol. 4, no. 2, pp. 100 105, 2002.

[4] M. Alhassan, "Potentials of rice husk ash for soil stabilization," Assumption University Journal of Technology, vol. 11, no. 4, pp. 246-250, 2008.

[5] F. O. Okafor and U. N. Okonkwo, "Effects of rice husk Ash on some geotechnical properties of lateritic soil," Leonardo Electronic Journal of Practices and Technologies, no. 15, pp. 6774, 2009.

[6] R. M. Brooks, "Soil stabilization with fly ash and rice husk ash," International Journal of Research and Reviews in Applied Sciences, vol. 1, no. 3, pp. 209-217, 2009.

[7] A. S. Muntohar and G. Hantoro, "Influence of rice husk ash and lime on engineering properties of a clayey subgrade," Electronic Journal of Geotechnical Engineering, vol. 5, pp. 1-9, 2000.

[8] J. N. Jha and K. S. Gill, "Effect of rice husk ash on lime stabilization," Journal of the Institution of Engineers, vol. 87, pp. 33-39, 2006.

[9] M. Alhassan, "Permeability of lateritic soil treated with lime and rice husk ash," AU Journal of Technology, vol. 12, no. 2, pp. 115-120, 2008.
[10] B. R. Phani Kumar, S. Sharama, and B. Vara Prasad Rao, "Engineering behavior of a remolded expansive clay blended with Lime, calcium chloride, and rice-husk ash," Journal of Materials in Civil Engineering, vol. 20, no. 8, pp. 509-515, 2008.

[11] T. K. Roy, B. C. Chattopadhyaya, and S. K. Roy, "Effect of lime on the properties of subgrade of roads with addition of rice husk ash," in Proceedings of the International Grains Conference (IGC'09), pp. 175-179, Guntur, India, 2009.

[12] ASTM C618-03, "Standard specification for coal fly ash and raw or calcined natural pozzolan for use as a mineral admixture in portland cement concrete," American Society for Testing of Materials, Pennsylvania, Pa, USA, 2003.

[13] A. Sridharan, N. S. Pandian, and P. S. Prasad, "Classification of coal ashes for geotechnical engineering practice," in Proceedings of the International Conference on Civil Engineering, pp. 738-745, Indian Institute of Science, Bangalore, India, 2001.

[14] N. S. Pandian, "Stabilization of expansive soil with fly ash," in Proceedings of the National Symposium on Advances in Geotechnical Engineering, pp. 81-89, Karnataka Geotechnical Center of Indian Geotechnical Society, Karnataka, India, 2004.

[15] J. L. Eades and R. E. Grim, "A quick test to determine lime requirement for lime stabilization," Highway Research Records, vol. 139, pp. 62-72, 1966.

[16] ASTM D2487-10, "Standard practice for classification of soils for engineering purposes (unified soil classification system)," American Society for Testing of Materials, Pennsylvania, Pa, USA.

[17] ASTM D4318-10, "Standard test methods for liquid limit, plastic limit, and plasticity index of soils," American Society for Testing of Materials, Pennsylvania, Pa, USA.

[18] ASTM D698-07e1, "Standard test methods for laboratory compaction characteristics of soil using standard effort," American Society for Testing of Materials, Pennsylvania, Pa, USA.

[19] ASTM D2166-06, "Standard test method for unconfined compressive strength of cohesive soil," American Society for Testing of Materials, Pennsylvania, Pa, USA.

[20] ARMY TM 5-822-14 and Air Force AFJMAN 32-1019, "Soil stabilization for pavements," Department of the Army, the Navy, and the Air force, 1994. 

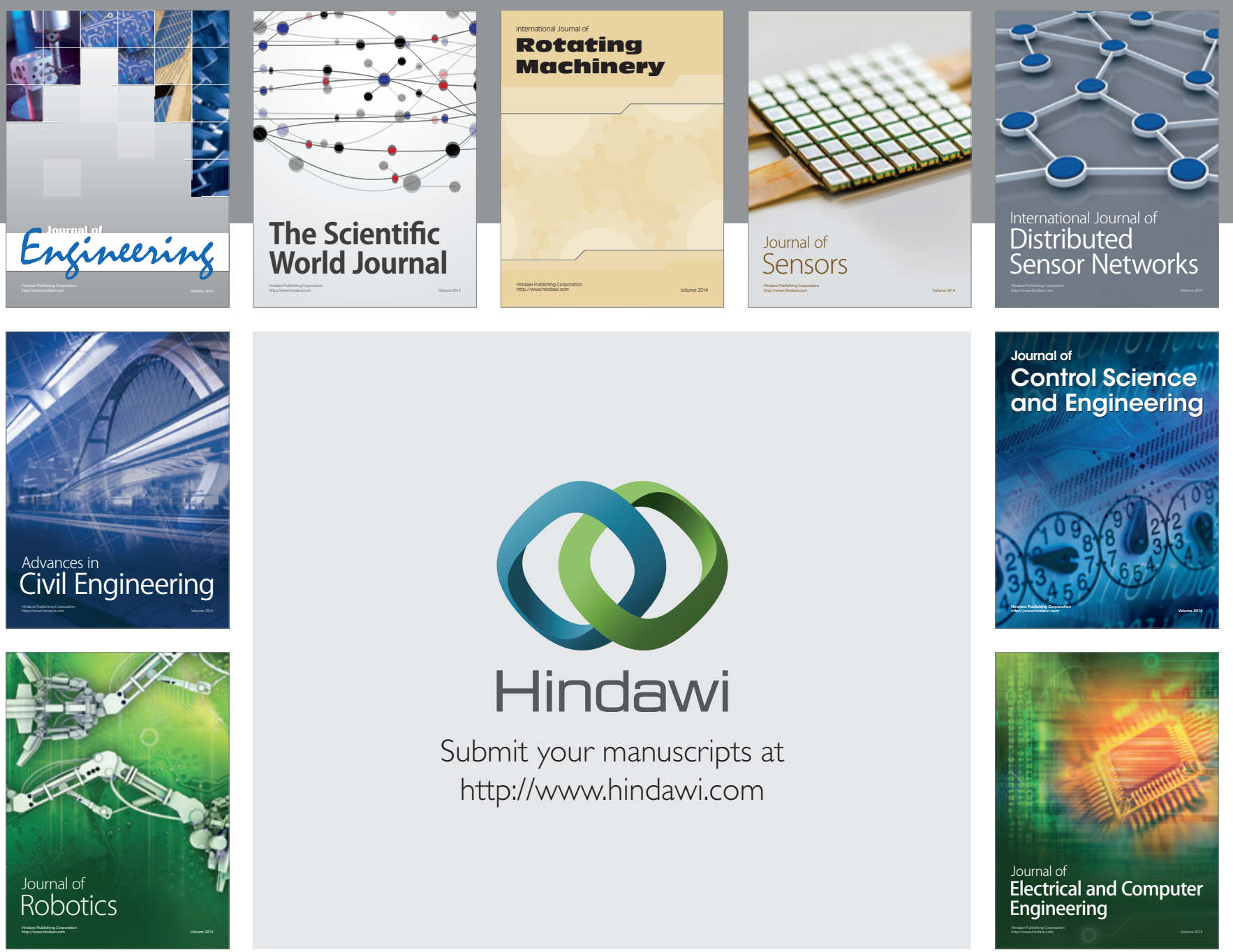

Submit your manuscripts at

http://www.hindawi.com
